\title{
Thematic group "Education” in Russian language (using analysis of Russian jargon dictionary as an example)
}

\author{
K. O. Selezneva ${ }^{1,2}$
}

${ }^{1}$ Voronezh State University, 43 Narodnaya str., Borisoglebsk, Voronezh Region 397160, Russian Federation 2 Krasnodar Air Force Institute for Pilots, 35 Dzerzhinskiy str., Krasnodar 350090, Russian Federation

DOI: $10.18255 / 2412-6519-2021-2-212-222$

Research Article

Full text in Russian

The article is devoted to the lexemes which are entered into the composition of the thematic group "Education". Some lexemes from Russian jargon dictionary are used. Solid sorting is used as a method. There is a list of the lexemes which are in the groups and minigroups in the thematic group «Education» as a result of the author's study. The author has done systematization and classification of these lexemes. The author's study gave an opportunity to sort out the following subgroups and minigroups: Students' names, Actuals' names that are connected with education learning process, Teachers' names, School subjects, Educational institutions, Educational departments, Separate workers' names in education, Marks, Students and teachers' names of several educational institutions, Forms of control and types of accounting, Allusions that appear after specific teachers, students and educational workers mentioning. Some subgroups have the following minigroups: Students' names connecting to their attitude to the study process, Students' names depending their department, Common students' names, Students' names depending their grade, Foreign students' names, Students' names depending their duties and privileges, Students' names depending their interests, Students' names depending their form of studying, Teachers' names depending subjects, Teachers' names depending the allusions connecting with the subject they teach, Common teachers' names.

Keywords: thematic group; education; jargon; solid sorting method; vocabulary data; marks

INFORMATION ABOUT THE AUTHORS

\begin{tabular}{l|l} 
Selezneva, Kristina 0. & $\begin{array}{l}\text { E-mail: kireeva_kristina@mail.ru } \\
\text { Cand. Sc. (Philology), Associate Professor }\end{array}$
\end{tabular}

For citation: Selezneva K. O. Thematic group "Education" in Russian language (using analysis of Russian jargon dictionary as an example) // Social'nye i gumanitarnye znanija. 2021. Vol. 7, No 2. P. 212-222. (in Russ.) 


\title{
Тематическая группа «Образование» в русском языке (на примере анализа Большого словаря русского жаргона)
}

\author{
К. О. Селезнева ${ }^{1,2}$
}

1Борисоглебский филиал ФГБОУ ВО Воронежский государственный университет, ул. Народная, 43,
Борисоглебск, Воронежская обл., 397160 , Российская Федерация
${ }^{2}$ Краснодарское высшее военное авиационное училище лётчиков, ул. Дзержинского, 135, Краснодар,
350090, Российская Федерация

DOI: $10.18255 / 2412-6519-2021-2-212-222$

удК 81

Научная статья

Полный текст на русском языке

В статье рассматриваются лексические единицы, входящие в тематическую группу «Образование». Материалом послужили те из них, которые содержатся в Большом словаре русского жаргона. Методом сплошной выборки были отобраны единицы, относящиеся к исследуемой тематической группе. В результате получился список лексических единиц, которые входят в подгруппы и мини-группы тематической группы «Образование». Автором статьи были проведены систематизация и анализ полученных данных. Проведенное автором исследование позволило выделить следующие подгруппы и минигруппы: Наименования учащихся, Наименования реалий, связанных с образованием и учебным процессом, Наименования педагогов, Наименования учебных предметов, Наименования учебных заведений, Наименования учебных подразделений, помещений и мест, Наименования отдельных работников в сфере образования, Наименования оценок, Наименования учащихся/преподавателей определенных учебных заведений, Наименования видов контроля и форм отчетности и Аллюзии, возникающие при упоминании отдельных преподавателей, учащихся и работников образования. Некоторые подгруппы имеют в своём составе следующие мини-группы: Наименования учащихся по отношению к учёбе, Наименования учащихся в зависимости от направления обучения, факультета, специальности, Общие наименования учащихся, Наименования учащихся в зависимости от курса и класса, на котором (в котором) они обучаются, Наименования иностранных студентов, Наименования учащихся в зависимости от получаемых ими льгот и исполняемых обязанностей, Наименования учащихся по интересам, Наименования учащихся в зависимости от форм обучения, Наименования педагогов по преподаваемому предмету, Наименования педагогов по реалиям, связанным с преподаваемой дисциплиной, Общие наименования педагогов.

Ключевые слова: тематическая группа; образование; жаргон; метод сплошной выборки; словарные данные; пометы

\section{ИНФОРМАЦИЯ ОБ АВТОРАХ}

Селезнева, Кристина Олеговна

Email: kireeva_kristina@mail.ru

Кандидат филологических наук, доцент кафедры социальных и гуманитарных дисциплин, старший преподаватель

отдельной дисциплины

Для цитирования: Селезнева К. О. Тематическая группа «Образование» в русском языке (на примере анализа Большого словаря русского жаргона) // Социальные и гуманитарные знания. 2021. Том 7, № 2. C. 212-222.

(C) Селезнева К. О., 2021

Статья открытого доступа под лицензией СС BY (https://creativecommons.org/licenses/by/4.0/) 
Предметом нашего исследования является тематическая группа (ТГ) «Образование». Данная тематическая группа выбрана нами не случайно. Напомним, что в соответствии с принятой Национальной доктриной образования в Российской Федерации до 2025 года приказом Минобразования России от 11.02.2002 N 393 принята Концепция модернизации российского образования на период до 2010 года, которая взаимосвязана с основными направлениями социально-экономической политики Правительства Российской Федерации на долгосрочную перспективу и определяет приоритеты и меры реализации генеральной, стратегической линии в модернизации образования. Совершенно очевидно, что модернизация невозможна без реформ. В каждой семье есть бывшие, нынешние или будущие учащиеся, поэтому вопросы реформы сферы образования в России затрагивают интересы каждой семьи. Лексика, в свою очередь, наиболее подвижный языковой пласт, который отражает не только политические процессы, но и отношение к ним людей. Именно поэтому интересно наблюдать за появлением новых лексических единиц, новых значений и оттенков значений у привычных лексем в сфере образования.

Наиболее «свободной» и наиболее быстро реагирующей на подобного рода изменения является, на наш взгляд, жаргонная лексика. Лингвистический энциклопедический словарь (ЛЭС) дает следующее определение жаргону: «Жаргон - разновидность речи, используемая преимущественно в устном общении отдельной относительно устойчивой социальной группой, объединяющей людей по признаку профессии, положения в обществе, интересов или возраста (молодёжный жаргон). Отличается специфической лексикой и фразеологией и особым использованием словообразовательных средств» [1]. Л. И. Скворцов предлагает следующую трактовку термину «жаргон»: «Жаргон - социальная разновидность речи, характеризующаяся, в отличие от общенародного языка, специфической (нередко экспрессивно переосмысленной) лексикой и фразеологией, а также особым использованием словообразовательных средств. Жаргон является принадлежностью относительно открытых социальных и профессиональных групп людей, объединенных общностью интересов, привычек, занятий, социального положения и т. п. (например, жаргон моряков, лётчиков, спортсменов, учащихся, актёров, заключённых). В нестрого терминологическом смысле «жаргон» употребляется для обозначения искажённой, вульгарной, неправильной речи [то же, что арго], но с пейоративной, уничижительной, оценкой» [2].

Отметим, что в свете реформы системы образования в РФ лингвистические исследования в области лексики, относящейся к данной сфере, активно развиваются [3; 4; 5]. Так, учёные Воронежской лингвистической школы занимаются изучением данной темы, что нашло своё отражение в работах Д. В. Козельской, М. А. Стерниной, К. О. Селезневой [6; 7]. Не ослабевает интерес ученых-филологов к вопросам изучения факторов, принципов, особенностей функционирования жаргона [8; 9; 10 ; 11; 12 ; $13 ; 14]$.

Принимая во внимание всё вышеизложенное, актуальность исследования тематической группы «Образование» в русском языке на примере анализа Большого словаря русского жаргона не вызывает сомнения.

Методом сплошной выборки из Большого словаря русского жаргона [15] нами были выписаны слова, принадлежащие к исследуемой тематической группировке. В итоге нами был получен базовый список данной ТГ, состоящий из 565 единиц. Именно он послужил материалом для дальнейшего исследования. Полученные данные были нами проанализированы, систематизированы и структурированы в более 
мелкие группы и подгруппы. Рассмотрим более подробно список тематических групп и входящих в их состав подгрупп в порядке убывания:

\section{1. Наименования учащихся (110):}

1.1. Наименования учащихся по отношению к учёбе (35): Аккуратист - прилежный ученик, отличник; Борода 3 - знаток, хорошо разбирающийся в учебном материале ученик; Бот - отличник, примерный ученик; зубрила; Ботан - отличник, прилежный, примерный ученик; 2 Ботаник 1, Ботанчик- отличник, прилежный ученик; Ботанка - отличница, примерная ученица; Букварь 3 - старательный ученик, отличник; Букварь 4 - двоечник, второгодник; Казёнщик - прогульщик; Комар 1 - неусидчивый ученик; Молекула 2 - студент, плохо подготовившийся к занятию; Олимпик - студент, не сдавший зачет по физвоспитанию, физической подготовке; Патриот - отличник, зубрила; Пахарь 2 - прилежный ученик, студент; Политик 2 курсант военного училища, лишенный отпуска из-за нарушения дисциплины; Промокашка 2 - прилежная школьница; Пустырь 1 - двоечник, несообразительный ученик; 1 Пушкин 5 - отличник; Рюхач - способный, эрудированный учащийся, отличник; Cuноптик 2 - прилежный ученик, отличник; Смертник 3 - кандидат на отчисление; Павший смертью храбрых - об ученике, сбежавшем с урока; Стерильный - ничего не знающий, не подготовившийся к экзамену, к зачету; Стилл - прилежный ученик, зубрила; Фотограф 2 - учащийся, который списывает выполненную работу у других; Хвостатый 1, Хвостист - студент, имеющий академическую задолженность; Хвостун - отстающий, неуспевающий студент; Аленький цветочек 1 - ученик у доски; Чеpen 3 - отличник; Чеснок 3 - отличник, зубрила; Чистый 2 - ничего не знающий, не подготовившийся к занятию; Шуршало 1 - отличник; Ягель - отстающий ученик, двоечник.

1.2. Наименования учащихся в зависимости от направления обучения, факультета, специальности (28): Абсира́нт - аспирант; Бином 1 - студент факультета информатики; 2 Бух - студент отделения «Бухгалтерский учёт и аудит»; Вокалюга 1 учащийся консерватории по классу вокала; Дуб 3 - студент привилегированного факультета; Журик - студент факультета журналистики; Зверь 2 - студент биологического факультета; Интенсивник - студент, изучающий иностранный язык интенсивно (по особой программе); Истерик - студенты исторического факультета; Кадет 1 - ученик кадетского класса - класса мужского воспитания; Kaдет 2 - курсант военного училища, школы милиции; Kadem 3 - курсант, проходящий практику на зарубежном судне; Карась 2 - курсант военного училища; Киллер 3 - студент отделения, факультета единоборств; Классик 1 - студент отделения классической филологии; Корнет 2 - курсант военного училища, школы МВД; 1 Куро́к 5 - курсант военного училища; Милитарист 2 - курсант училища МВД; Начальник 2 - студент факультета начальных классов (в пединституте); Паяльник 1 - студент, избравший техническую специализацию (в радиотехнике, обеспечении компьютеров); Пимношка - студентка факультета педагогики и методики начального образования (ПиМНO); Tonmyн 7 курсант военного училища; Tурист 3 - студент отделения «Менеджмент в сфере туризма»; Филолух - студент-филолог; Фин - студент отделения «Финансы и кредит»; Халат 5 - студент медицинского института; Шизик 3- студент-физик; Юнкер - курсант военного училища.

1.3. Общие наименования учащихся (22): Aбита́ 1 - абитуриент, абитуриентка; Aбита́ 2 - абитуриенты; Абите́нь 1 - абитуриент, абитуриентка; Абите́нь 2 абитуриенты; Абиту́ра - абитуриенты; Академик 3 - студент, находящийся в академическом отпуске; Бурса́к - студент, учащийся; Вуз 1 - о девушке, которая учится 
в вузе для того, чтобы найти мужа; Зажигалка 4 - воодушевленная, бойкая абитуриентка; Зёма 2 - одноклассник, проживающий в одном доме, в одном дворе с говорящим (земляк); Клякса 1 - школьница; Крыска 3 - школьник, ворующий в классе и в гардеробе; 2 Мыло - о студентах, которые пишут в стиле соцреализма, подражают А. А. Мыльникову (нар. худ. СССР); Обиженник 3 - презираемый и унижаемый всеми ученик; Основной 2 - ученик, представитель школьной «элиты», выделяющийся материальным положением или умственными способностями, эрудицией; Пацан 5 - неформальный лидер в классе, в школе; Студень 2 - студент; Студиозус - студент; Целёвщик - человек, обучающийся в целевой аспирантуре; Шерстяной 2 неформальный лидер в школе; Шлепо́к - курсант; Шмонала - вымогатель денег, сладостей (обычно старшеклассник).

1.4. Наименования учащихся в зависимости от курса и класса, на котором (в котором) они обучаются (13): Aдидас 3 - курсант III курса военного училища; Вторяк 3 - студент второго курса; А́шки 1 - ученики класса «А»; Бэшки 1 - ученики класса «Б»; Дед 4 - старшеклассник; 1 Енот 1 - студент первого курса; Козерог - студент-первокурсник; Минус - студент I курса военного училища; Молодой 2 - первокурсник; Первак - студент первого курса; Равно - курсант второго курса военного училища; Третьяк 1 - студент третьего курса; Четвертак 4 - студент четвертого курса.

1.5. Наименования иностранных студентов (6): Брат 2 - иностранный студент (обычно из стран Азии, Африки и Латинской Америки); Друг 1 - иностранный студент (обычно из стран Азии, Африки и Латинской Америки); Нуль 1 - студентыиностранцы, начинающие изучать язык с нуля; Форин 2, Фрэнд, Френд 2 - иностранный студент.

1.6. Наименования учащихся в зависимости от получаемых ими льгот и исполняемых обязанностей (3): Бесплатник 2 - ученик, пользующийся правом бесплатного питания в школьной столовой; Казначей - человек, получающий стипендию на группу; Раб 2 - студент младшего курса, который помогает старшекурсникам делать дипломный проект.

1.7. Наименования учащихся по интересам (2): Ашхлорик - ученик, увлекающийся химией, разбирающийся в ней; Примат 2 - студент, занимающийся прикладной математикой.

1.8. Наименования учащихся в зависимости от форм обучения (1): Заушник - студент-заочник.

2. Наименования реалий, связанных с образованием и учебным процессом (94): Академ, Академка - академический отпуск; Бега́ - учебный марш-бросок в армии; 1 Бомба 4 - шпаргалка на большом листе бумаги с полным ответом на вопрос; Бук 1 - книга; Ваучер - талон на обед в столовую; Верхнее - высшее образование; Военка 2, Война 3 - занятия на военной кафедре; военная подготовка в вузе, в школе; Воёшка - занятия по военной подготовке; Во́nли - журнал «Вопросы литературы»; Вспашка озимых, Сено-Солома, Шерсть 1 - неаккуратная штриховка; Гармошка 1 шпаргалка на длинном узком листке бумаги, свернутая гармошкой; Графики - графические уравнения; Датцзыбао, Дацзыбао - студенческая стенная газета; Двойник 3 дневник; Диссер, Диссертуха - диссертация (обычно кандидатская); Диффуры - дифференциальные уравнения; Домаха - домашнее задание; Домашка 1 - домашняя работа, письменное домашнее задание; Допинг - доплата к стипендии на питание; Завал 4 - получение неудовлетворительной оценки на экзамене; Задвигон 1 - прогул, пропуск урока, лекции без уважительной причины; Иностранка 2, Инострань 1 - библиотека иностранной литературы в Москве; Камчатка 2 - последние парты в классе, 
за которыми сидят плохие ученики; Карабах - провал на экзамене; Картонка 1 - зачетная книжка; Картошка 1 - осенние сельскохозяйственные работы, выполняемые студентами; 1 Кирпич 1 - очень толстая книга; Комиксы 2, Медовый месяц - каникулы в военном училище; Курсы кройки и шитья 1 - курсы повышения квалификации хирургов; Лом 1- карандаш; Я помню чудное мгновенье - о каникулах; Меридиан - праздник, вечеринка, посвящённая завершению половины срока обучения; Мозг 1 - учебник, учебники; Мозгобойка - родительское собрание; Мыты - воспитательная работа среди заключенных; Бухенвальский набат - звонок на урок; Надрочка, Тяжелуха учёба; зубрежка; Назидалово - поучение, нотация, наставление; Ночное - самостоятельные занятия на протяжении всей ночи; Французский отпуск - пропуск занятий без уважительной причины; Ошейник 1 - пионерский галстук; Папирус 1 - конспект; Пара 2 - лекция, учебное занятие, состоящее из двух спаренных академических часов; Патруль - дежурный или группа дежурных по школе; Пенсия 2, 1 Плата, Степуха, Cтепь, Стёпа 1,Стёпка, Стип, Стипа, Стипенсия, Стипон, Стипуха - стипендия; Поимёнка - опрос учащихся; Портфик - портфель; Приговор 3 - объявление результатов экзаменов; 1 Прицеп 4 - небольшой рюкзак, сумка, которую носят на плече, за спиной; Продлёнка - форма внеклассной работы с учениками (в школе) по завершении занятий; Рабство - система взаимопомощи студентов при написании дипломных работ; Русиш 2 - урок русского языка; Я бродил среди скал, я Европу искал - об уроке географии; Скафандр 3 - школьная форма; Сменка 5 - сменная обувь, которую ученик надевает, приходя в школу; Строяк - студенческий строительный отряд; Студик - студенческий билет; Торба 2 - школьный портфель; Звериная тропа - дорога в школу; Ушко 2 - уважительная причина отсутствия на занятиях; Форточка 4 - ничем не занятое время, разрыв в расписании занятий; Форшмачка - форма учащихся профессионально-технических училищ; Халяву (халявку) кормить - название предэкзаменационного «ритуала» привлечения удачи, когда в окно бросают вкусную пищу; Халява, ловись! - ритуальное восклицание перед экзаменом; Хвост 7 - академическая задолженность, несданный зачет, экзамен; Хождение по мукам - урок; Целёвка - целевая аспирантура; Числогрыз 2 - калькулятор; Шар 7 - балл (в системе оценки знаний); Шкурка 2 - обложка (книги, тетради); Шпага 3, Шпора 6 - шпаргалка; Много шуму из ничего - классный час; Экватор - время после зимней сессии на третьем курсе, середина учебы в вузе, традиционный праздник студентов, прошедших половину срока обучения в вузе.

\section{3. Наименования педагогов (86):}

3.1. Наименования педагогов по преподаваемому предмету (22): Мастак 2, Трудяга - мастер производственного обучения; Мляшница - преподавательница методики литературы; Мряшница - преподавательница методики [преподавания] русского языка; Немка 2 - учительница немецкого языка; Обэжешник, Обэжист, Обэжук, Обэжун - учитель, преподаватель ОБЖ - основ безопасности жизнедеятельности; Обэжучка - учительница, преподавательница ОБЖ; Пеша 2, Пешка 3 - учительница пения; Разговорник - специалист по разговорной практике; Русачка, Русичка - учительница русского языка; Современист, Современщик- преподаватель современного русского языка; Сряшница - преподавательница современного русского языка; Трудила, Трудило - учитель труда; Цивилизатор - преподаватель предмета «основы цивилизации»; Эмхэкачка - учительница, преподающая МХК (предмет «Мировая художественная культура»). 
3.2. Наименования педагогов по реалиям, связанным с преподаваемой дисциплиной (21): Амёба 2 - учительница зоологии и биологии; Баян Баяныч - учитель музыки; Биссектриса 1 - учительница математики; Глобус 1 - учитель географии; Зверь 1, Пестик 1, Самец 1- учитель биологии; Лягушка 2 - преподаватель физиологии; Мензурка 2, Молекула 1, Пробирка 1, Селитра 1 - учительница химии; Мистер Икс, Два в квадрате - учитель математики; Семядоля, Тычина 1, Тычинка 1 учительница биологии; Синекдоха, Точка 1 - учительница русского языка и литературы; Хромосом 1, Хромосома 2 - преподаватель генетики.

3.3. Общие наименования педагогов (16): Мастак 3, Тичер 2, Чирик, Педик 3 учитель; Преп, Препак, Препод - преподаватель; Препо́да, Преподша - преподавательница; 2 Репка - Женщина-репетитор; Свой 2 - демократически настроенный преподаватель, понимающий проблемы студентов, нетребовательный на экзамене; Тыча учительница, преподавательница; Утка 3 - учительница в общеобразовательной школе ИТУ; Халдей 5 - педагог общеобразовательной школы в ИТК; Чира 2 - учительница; 2 Шкраб - учитель общеобразовательной школы в ИТУ.

3.4. Наименования педагогов по именам, отчествам, фамилиям и их изменениям (12): Барбариска - прозвище учительницы с отчеством Борисовна; Васьвась 1, Вась-Вась - прозвище учителя по имени Василий Васильевич; Васьгав - прозвище учителя по имени Василий Гаврилович; 4 Веник - прозвище учителя по отчеству Венедиктович; Вергена - прозвище учительницы по имени Вера Геннадьевна; 2 Вермишель - прозвище учительницы по имени Вера Михайловна; Всеболдович - прозвище учителя по отчеству Всеволодович; Горилла 2 - прозвище учительницы с отчеством Гавриловна; 2 Макарона 1 - женщина (как правило, учительница) по отчеству Макаровна; Сырник 3 - учитель по имени Сергей Николаевич; Харя - учительница с отчеством Харитоновна.

3.5. Наименования классного руководителя, воспитателя (11): Аракчеев 1 классный руководитель; Воспит - классный руководитель; Воспитка, Bосnитуха воспитательница (в школе-интернате, группе продленного дня, пионерском лагере); Жандарм - классный руководитель; Классуха - классная руководительница; $М a-$ мочка 1 - воспитательница, командир отряда в женской колонии; Питка - воспитательница (в колледже, техникуме, летнем лагере, группе продленного дня); Скрипка 5 - классный руководитель; Cmapnem - старший воспитатель; Cтарпетка - старшая воспитательница.

3.6. Наименования педагогов по внешнему виду, внешности (2): Батискаф 3 - прозвище невысокой полной учительницы в круглых очках; Биолошадь - крупная, физически сильная учительница биологии.

3.7. Наименования педагогов по темпераменту (2): Гестаповна - прозвище очень строгой учительницы; Тигра 2 - властная, требовательная учительница.

4. Наименования учебных предметов (62): Административка - административное право; Античка - античная литература; Всемирка - история всемирной литературы; Выразилка - выразительное чтение; Вышак 3, Вышка 2 - высшая математика; 2 Гроб 2 - гражданская оборона; Диамат - диалектический материализм; Древнеруха - древнерусская литература; 2 Зару́ба, Зарубе́га, Зарубежка 1- зарубежная литература; Зарубежка 2 - экономическая география зарубежных стран; Зёма 3 - землеведение; Зоофили́я - зоология; 2 Игра - историческая грамматика; Истмат 1 - исторический материализм; Истмат 2 - история математики; Капээсня - история КПСС; 2 Край - краеведение; Литвед - литературоведение; введение в литературоведение; Литера́ча, Литра́ча - литература; Матлы - математическая логика; Махало́вка 5 - 
дирижирование; Медпсих - медицинская психология; Курсы кройки и шитья 2 - спецкурс по хирургии в медицинском институте; Tут моя могила - теория машин и механизмов; Другая моя могила - детали машин и механизмов; Мряха - методика [преподавания] русского языка; Муде́ния - механика управляемых движений; Начерталка начертательная геометрия; Обомжение - ОБЖ - основы безопасности жизнедеятельности; Общага 2 - обществоведение; Отечка - отечественная история; Пеша 1, Пешка 2 - пение; Русиш 1 - русский язык; Новый русский - современный русский язык; Свинка 3 - свиноводство; Совлит 1 - советская литература; Совлит 2, Современка - современная литература, современный литературный процесс; Conромат, Conромуть сопротивление материалов; Спец 6 - спецкурс, спецсеминар; 1 Спид 1 - социально-политическая история двадцатого века; Сряшник - современный русский язык; Странноведение - страноведение; Течка 2 - отечественная история; Тыр-пыр - теория и практика периодической печати; Уголовка - уголовное право; Физвос 1, Физер, Физра, Физуха - физическое воспитание, физкультура; Фрэн, Фрэнч, Френч - французский язык; Чтеша, Чтешка - урок чтения; Шкаф 3 - школьный курс физики.

5. Наименования учебных заведений (61): Бастилия, Морковка 2 - главное (высотное) здание МГУ в Москве; Бессрочка 2 - специальное профессионально-техническое училище для детей до 14 лет; Бу́рса - любое учебное заведение (школа, ПТУ, университет и т. п.); Герцовник - педагогический университет им. А. И. Герцена в СанктПетербурге; Говназия - гимназия; Гужатник, Путяга 1, Сорбонна 3, Фазанка 2, Чушок профтехучилище, колледж; Зона 2, Казёнка 2, Скул - школа; Зоопарк 3, Короядка - спецшкола для трудновоспитуемых детей; Ипполитивка - музыкальное училище им. Ипполитова-Иванова в Москве; Кембридж - профессионально-техническое училище; Керосинка 2 - Московская академия нефти и газа им. И. М. Губкина; Колледж - институт; 2 Кулёк 2 - кулинарное училище; Лесопилка - лесотехническая академия; Лумумба́рий - университет дружбы народов им. Патриса Лумумбы; Мана́ция - сельское профтехучилище; Мед 1 - медицинский институт; Медуха - медицинское училище, колледж; 2 Ми́мо - Московский государственный Институт Международных Отношений; Бу́рса зека, Сорбонна 2 - общеобразовательная школа для осужденных в ИТК; Монта́га - строительно-монтажный техникум; Морозильник, Холодильник 4 - институт холодильной промышленности; Мужикально-педерастическое чудилище имени братьев Гнусиных Московское музыкально-педагогическое училище им. Гнесиных; Музыкалка - детская музыкальная школа; Муха 6 - Высшее художественно-промышленное училище им. Мухиной в Санкт-Петербурге; 1 Пед 1 - педагогический институт; Педрочилище - хореографическое училище им. Вагановой в Санкт-Петербурге; Педулище - педучилище; Педуха - педагогический институт; 2 Плешка - академия народного хозяйства им. Плеханова; Сиротка - детский дом; Система 3 - военно-морское училище; Ситет университет; Слежка - высшая следственная школа; Сорбонна 1 - школа для детей с замедленным психическим развитием; 2 Соха - сельскохозяйственная академия (СХА); 2 Строгач - Строгановское училище в Москве; Терем, Технарь 1 - техникум; Тряпка 3, Тряпочка 2 - университет технологии и дизайна в Санкт-Петербурге (бывш. Институт текстильной и легкой промышленности); Уни, Универ, Уник - университет; Учебка школа младшего командного состава; Бакланья хаза - спортивная школа бокса, восточных единоборств; Шаолинь - военное училище; Школа 1 - любое высшее учебное заведение; Щепка - Театральное училище им. М. Щепкина в Москве; Щука 6, Щучка 3 - Театральное училище им. Б. Щукина в Москве. 
6. Наименования учебных подразделений, помещений и мест (39): 2 Библия, Блевотека, Бляотека - библиотека; Быканат, Драконат - деканат; Военка 1 - военная кафедра в вузе; Гестапо 2 - кабинет директора; Деканат, КПД, КПЗ, Дворец съездов, Тубаркас, Тубзик- туалет; 1 Загон 3, Свинарник - класс, аудитория; 1 Загон 4 физкультурная раздевалка; Зверофак - биологический факультет; Камбуз - столовая в военно-морском училище; Келья 2 - комната в общежитии; Коша́ра 2, Общага 1, Peзиденция - общежитие; Махало́вка 4 - дирижерско-хоровое отделение в вузе, колледже; Дворянское гнездо, Осиное гнездо, Серпентарий - учительская; Кошачий городок 1 - студенческий городок; Мишка 2 - дворик перед факультетом журналистики МГУ, место встреч, тусовок молодёжи; Много хочешь - мало получишь, Рыгаловка 1 о школьной столовой; Музла́ - общежитие музучилища; Примат 1 - факультет прикладной математики; Псарня 1 - казарма, общежитие, учебное заведение МВД или КГБ, ФСБ; 1 Спид 2 - совет при директоре; 1 Фак - факультет; Физвос 2 - факультет физического воспитания в пединституте; Халдейская - учительская в общеобразовательной школе ИТУ; Чпок - буфет в военном училище; Шизмат - физико-математический факультет.

7. Наименования отдельных работников в сфере образования (33): Аракчеев 2, Дерюга, Дерюжка, Дир, Дирик, Дирюга, Дирюжник, Ди́ря, Кореш 3, Мюллер 2, Пастух 6, Хозяин 6, Чабан 2, Шеф 3- директор школы; 2 Бабуля, Дирюжница - женщина директор школы; Быкан - декан; Гав-Гав 1, Зек, Зэк - заведующий кафедрой; 1 Гусь 3 директор школы в ИТУ; Коме́нда - комендант общежития (о женщине); Мазай- ректор; Али-баба и сорок разбойников 1 - директор школы и учителя; Проф, Профи 2, Старик 1 - профессор; Голый (сухой, холодный) профессор - человек, получивший звание профессора, не защищая докторскую диссертацию; Проэректор - проректор; Рук научный руководитель; Шеф 4 - руководитель курсовой или дипломной работы.

8. Наименования оценок (32): 1 Гусь 1, Двойбан, Двушка 2, Двушник, Дупль, Кровать 2, Напильник 3, Пара 1, Паяльник 7, Твикс 2, Утка 1, Цара, Цвайбан, Цвайка, Цица, Чекуша - двойка, неудовлетворительная оценка; Отл 1, Петрофан 2, Петух 10, Питекантроп 2, Пятак 6, Файф 2, Файфок 2, Файфушник 2 - оценка «отлично»; Государственная оценка, Международная оценка, Тройбан, Тройной, Трюндель 2, Удочка 5 - тройка, оценка «удовлетворительно»; 2 Хор, Хорёк 7 - оценка «хорошо».

9. Наименования учащихся/преподавателей определенных учебных заведений (19): Быдлёнок, Быдло́к, Быдлюк, Гуж 3, Интеллигент 2, Птушка, Путяга 2, Ремесло 1 - учащийся ПТУ; Гужевичка - учащаяся профтехучилища, колледжа; Красивый 1, Шпито́нок - воспитанник детского дома; Маёвец - студент или преподаватель МАИ; Майовец - студент МАИ; Мендель - студент МХТИ им. Менделеева; Мимозник студент и выпускник МГИМО - Московского государственного института международных отношений; Мимошник - студент, аспирант или преподаватель МГИМО; 1 Пед 2, Педик 2 - студент педагогического института, университета; Слушак - слушатель военной академии.

10. Наименования видов контроля и форм отчетности (15): Автома́т 1 - зачет, полученный автоматически по результатам текущей успеваемости; Госы - государственные экзамены; Запа́ра 2 - экзамен; Исповедь 4 - экзамен; Клоаквиум - коллоквиум; Коло́к - коллоквиум; 3 Контра, Контрабанда - контрольная работа; Курсач, Курсовик, Курсовуха - курсовая работа; 2 Лаб (=1 Лаб) - лабораторная работа; Великая Запара - сессия; Экзема - экзамен. 
11. Аллюзии, возникающие при упоминании отдельных преподавателей, учащихся и работников образования (14): Гном 2 - преподаватель экономики; Воевода - учитель НВП (начальной военной подготовки); Истеричка - учительница истории; Козёл опущения - учитель физкультуры (т. к. основное упражнение - наклон и подъём); Погонщик ослов, Хип-хоп - учитель физкультуры; Самоделкин 2 - учитель труда; Сурепка - учительница биологии; Хаки - учитель ОБЖ (основы безопасности жизнедеятельности) или военной подготовки; Химера 2, Химоза - учительница химии; Чича 3- учительница английского языка; Шизик 2 - учитель физики; Шизичка учительница физики.

Анализ полученных данных показал, что наиболее многочисленной является группа Наименования учащихся (110 единиц), затем идёт группа Наименования реалий, связанных с образованием и учебным процессом (94 единицы) и, наконец, группа Наименования педагогов (86 единиц) «замыкает тройку лидеров». Обращает на себя внимание тот факт, что именно первая и третья из названных групп имеют в своём составе более мелкие подгруппы и мини-группы, причём примерно равное их количество. Так, в состав группы Наименования учащихся входит 8 подгрупп, а в состав Наименования педагогов - 7 подгрупп. На наш взгляд, это объясняется тем, что в процессе обучения самым важным является взаимодействие «учитель-ученик», что находит своё отражение в языке в виде разнообразных наименований каждого участника данного процесса.

Преобладание наименований учащихся и педагогов в студенческом и школьном жаргоне (такие лексические единицы приводятся в словаре с пометами Студ. и Шк.) объясняется тем, что именно для этих категорий граждан данная сфера является главной. Она занимает практически всё их время, приходится, на наш взгляд, на тот период, когда человек «максимально открыт для словотворчества», готов принимать новое, не боится экспериментировать со словами, стремясь привлечь к себе внимание сверстников. Это подтверждается и тем фактом, что группа Наименования реалий, связанных с образованием и учебным процессом занимает второе место в списке и содержит 94 единицы, причём на многие реалии в словаре приводится по несколько лексических единиц.

Следует отметить, что подавляющее большинство слов, выявленных в ходе исследования, носят ярко выраженный иронический, пренебрежительный, а порой и шутливый характер. Такие лексемы в словарях приводятся с соответствующими пометами: Шутл., Ирон., Пренебр. (Пестик - Шутл.-ирон. Учитель биологии; Обэже́шник - Пренебр. Учитель, преподаватель ОБЖ - основ безопасности жизнедеятельности и т. д.).

Нельзя не принимать во внимание тот факт, что поколения молодых людей (именно студенческий и школьный жаргон представляет собой около 80 \% изученного материала) сменяются через каждые пять-семь лет, а это значит, что уже через пять-семь лет изменится и их жаргон - какие-то лексические единицы мы больше не услышим, появятся новые слова, новые значения и/или оттенки значений у привычных слов. Вот почему так важно успеть не просто их зафиксировать, а рассмотреть особенности образования и функционирования, что открывает широкое поле для дальнейшей исследовательской деятельности в рамках данной темы.

\section{Ссылки / References}

1. Лингвистический энциклопедический словарь / Гл. ред. В. Н. Ярцева. М.:

Сов. энциклопедия, 1990. 685 с. 
2. Скворцов Л. И. Жаргон // Русский язык. Энциклопедия. М.: Большая Российская энциклопедия: Дрофа, 1997. С. 129.

3. Николаева О. В. Когнитивные аспекты исследования Тематической группы «Высшее образование США»: дис. ... канд. филол. наук: 10.02.04. Владивосток, 2000.199 с.

4. Колосовская Е. В. Национально-культурная специфика языкового сознания русских и британцев на материале Тематической группы «воспитание»: дис. ... канд. филол. наук: 10.02.19. М., 2004. 179 c.

5. Селезнева К. О. Результаты компонентного анализа лексических единиц, входящих в состав тематической группы «Общие номинации педагогов» // Казанская наука. 2019. № 3 C. 99-103.

6. Козельская Д. В., Стернина М. А. Контрастивный семный словарь наименований школьных педагогических работников и учащихся в русском и английском языках. Воронеж: РИТМ, 2018. 88 с.

7. Селезнева К. О. Тематическая группа «Общие номинации педагогов» в русском и испанском языках // Казанская наука. 2018. № 9. С. 114-116.

8. Киреева К. О. Жаргонные наименования учителей и преподавателей в русском языке // Современные проблемы лингвистики и методики преподавания русского языка в вузе и школе: сборник научных трудов. Воронеж: Научная книга, 2009. Вып. 9. С. 60-71.

9. Иванников Е. Б. Языковая рефлексия в Интернет-жаргоне: дис. ... канд. филол. наук: 10.02.01. СПб., 2020. 179 с.

10. Ван Синхуа. Русский молодёжный жаргон в аспекте интерпретации вторичной языковой личностью: дис. ... канд. филол. наук: 10.02.01. Томск, 2020. 663 с.

11. Руденя Ж. И. Жаргонная лексика в современном молодёжном дискурсе и возможности её представления в словаре для изучающих русский язык как иностранный (на материале жаргонизмов, функционирующих в речи воронежской молодёжи): дис. ... канд. филол. наук: 10.02.01. Воронеж, 2017. 221 с.

12. Афанасова Н. В. Язык фикрайтеров в Рунете: особенности формирования и функционирования: дис. ... канд. филол. наук: 10.02.01. Елец, 2017. 249 с.

13. Зоркина К. В. Лингвопрагматические характеристики молодёжного сленга (на материале немецкого языка): дис. ... канд. филол. наук: 10.02.04. Волгоград, 2021. 213 с.

14. Пархоменко Е. В. Язык как способ бытия субъекта (на материале локальной языковой системы - воровского арго): дис. ... канд. филол. наук: 09.00.01. Волгоград, 2019. 166 с.

15. Мокиенко В. М., Никитина Т. Г. Большой словарь русского жаргона. СПб.: Норинт, 2001. 720 c. 